\title{
THE EFFECT OF HIGHER EDUCATION ON THE FORMATION OF ASSERTIVE BEHAVIOR BY STUDENT YOUTH
}

\author{
Marchuk Larysa Mykolaivna, \\ Candidate of Psychology, \\ Associate Professor of Pedagogy and Psychology Department \\ Uzhhorod National University \\ Immar4uk@gmail.com \\ orcid.org/0000-0002-1905-3132
}

The purpose of the article is to investigate the impact of higher education on the formation of assertive behavior. According to the stated goal, the following tasks are defined: 1) to analyze the assertive approach in a higher education institution; 2) determine the quality and level of assertiveness in the student environment.

Methods. Theoretical methods of research - analysis of approaches and results of studying the state of assertiveness in student youth. Practical methods - surveys, questionnaires. The empirical research, which is in the article described, was conducted by the method of continuous questionnaire survey of students of bachelors (psychology training course) 1-4 courses of the Higher Educational Institution of Uzhgorod National University. The author of the publication determined the level of assertive attitude of students in educational and other interactions in combination with the study of the level of respondents' awareness of the specified quality. The most characteristic for the actual situation students' views on the concepts of "assertiveness", "assertive personality", "assertive behavior" and the reasons for their assertive behavior are analyzed and presented. The importance of the assertive approach of a higher educational institution to the formation of assertiveness as a student's personal growth, his / her self-knowledge, ability to reflect, his / her self-actualization and self-actualization, his / her individual and social development are highlighted.

Results. In the course of the survey, aspects such as the limits of application of the concept of "assertiveness" in students' perceptions, the declarative and real level of assertiveness, its level in relation to the profession, in particular in the business sphere, were studied. The results of the study expand knowledge about assertiveness, features of assertive behavior of student youth and can serve as a basis for adjusting the pedagogical and educational practice of higher education institutions.

Conclusions. The results of the study of the influence of the university system on the student's consciousness in the process of development of assertive psychological qualities, indicated that in the process of education there is a gradual formation of the student not only as a professional, but also an assertive personality, which is able to adapt in social interaction through the formed assertive behavior. It is concluded that the use of educational technologies by universities, based on the practical aspect of assertive behavior and assertive communication. The presented research can be useful for educators and psychologists for monitoring and correction of assertive behavior of students, as well as being a criterion basis for building a training program aimed at the development of these characteristics.

Key words: assertive personality, assertive approach, emotional stability, trust, confidence, reflection.

\section{ВПЛИВ ВИЩОЇ ОСВІТИ НА ФОРМУВАННЯ АСЕРТИВНОЇ ПОВЕДІНКИ СТУДЕНТСЬКОЇ МОЛОДІ}

\author{
Марчук Лариса Миколаївна, \\ кандидат психологічних наук, \\ доцент кафедри загальної педагогіки та педагогіки вищої школи \\ ДВНЗ «Ужгородський національний університет» \\ Immar4uk@gmail.com \\ orcid.org/0000-0002-1905-3132
}

Мета статті - дослідити вплив вищої освіти на формування асертивної поведінки. Відповідно до поставленої мети визначені такі завдання: 1) проаналізувати асертивний підхід у закладі вищої освіти; 2) визначити якість і рівень асертивності у студентському середовищі.

Методи. Теоретичні методи дослідження - аналіз підходів і результатів вивчення стану асертивності у студентської молоді. Практичні методи - опитування, анкетування. Емпіричне дослідження, описане у статті, проводилося методом суцільного анкетного опитування студентів-бакалаврів (спеціальність: Психологія) 1-4 курсів ДВНЗ «Ужгородського національного університету». Автором публікації визначено рівень асертивного ставлення студентів у навчальній та інших взаємодіях у поєднанні 3 дослідженням ступеня інформованості респондентів про зазначену якість. Проаналізовано і представлено 
найбільш характерні для актуальної ситуації погляди студентів на поняття «асертивність», «асертивна особистість», «асертивна поведінка», а також причини їх асертивної поведінки. Виділено значення асертивного підходу вищого навчального закладу щодо формування асертивності як особистісного росту студента, його самопізнанню, умінню рефлексувати, його самореалізації й самоактуалізації, його індивідуальному і соціальному розвитку.

Результати. У ході опитування вивчені такі аспекти, як межі застосування поняття «асертивність» у сприйнятті студентів, декларативний і реальний рівень асертивності, іiі рівень щодо професії, зокрема в діловій сфері. Результати дослідження розширюють знання про асертивність, особливості асертивної поведінки студентської молоді та можуть слугувати базою для коригування педагогічної та освітньої практики вищих навчальних закладів.

Висновки. Підсумки дослідження впливу системи ЗВО на студентську свідомість у процесі розвитку асертивних психологічних якостей вказали, що у процесі навчання відбувається поступове формування студента не тільки як професіонала, а і як асертивної особистості, яка здатна адаптуватися в соціальній взаємодії через сформовану асертивну поведінку. Зроблено висновок про необхідність застосування вишами освітніх технологій, що базуються на практичному аспекті асертивного поводження й асертивного спілкування. Викладене дослідження може бути корисне педагогам і психологам для проведення моніторингів і корекції асертивної поведінки студентів, а також слугувати критеріальною основою побудови тренінгової програми, спрямованої на розвиток зазначених характеристик.

Ключові слова: асертивна особистість, асертивний підхід, емочійна стабільність, довіра, впевненість, рефлексія.

\section{Introduction}

In the conditions of transformation of modern society the study of problems of assertive behavior of student youth is of great theoretical and practical importance. Being the most dynamic part of society, young people occupy a special place in it because of their specific position in the social structure and the most important social functions in the process of social reproduction - continuity and restoration of existing social relations.

The assertive approach in education is established through communication styles, the value of which is important in terms of achieving effectiveness in social interaction. Based on activity, it is defined as a source of transformation or maintenance of vital human relationships that arise. From the perspective of the educational situation, defending one's view on communication style, content and purpose of education is regarded as an undesirable position. Therefore, there are many examples of directive pedagogical practice that dominates in Ukraine. Based on the principle of power centralization, such a pedagogical system is based on situations that do not require independent thinking, asserting their position. Criticality, creativity and initiative are more likely to be perceived as hindering a "holistic process". For higher education, this becomes a problem because the student is required to be analytical, independent of judgment, and able to acquire knowledge independently. Educational institutions that are trying to build excellent models face problems that have subjective and objective circumstances. (Pylypenko, 2010: 34-40).

The specificity of any future professional activity imposes a significant imprint on the formation and manifestation of assertiveness in the educational process of higher education. On the one hand, society needs high-moral professionals with a broad educational outlook, initiative and autonomous, who are able to improve their personality and activities systematically, constantly work on their development. On the other hand, the formation of a new social system in our country and the inclusion of the economy in the system of world economic relations, sets the task of professional development of future specialists not only to acquire professional knowledge and skills, but also to develop an independent active personality who has the skills of self-regulation, professional communication, which is based on assertive engagement rules.

\section{lem}

1. Theoretical substantiation of the prob-

The formation of assertive behavior is caused by the activation of positive psychological qualities, which is certainly very important in the process of becoming a person. Assertive behavior in this context - ensures the success of the individual, and on the other - eliminates such destructive psychological manifestations as aggression, passivity, tendency to depressive state, etc. That is why the problem of forming assertive behavior in the process of student learning becomes meaningful not only as a scientific value, but also applied systematically stimulating personal and professional self-development.

Based on the research of the Ukrainian scientists, refining their approaches, should emphasize that one of the most important conditions for promoting the assertiveness of the student is active social and psychological training in the process of professional formation of future specialists.

Despite the scientific interest of the researchers in the study of the studied phenomenon, 
nowadays there are problems that are connected with: identification of specific personality characteristics of assertive personality of youth, with peculiarities of manifestation of personal self-regulation, choice of ways of interaction with the surrounding reality, (constructive or destructive); with the desire of young people to preserve the integrity and development of their self, self-realization, self-actualization, self-development in the conditions of various activities.

The purpose of the article is to investigate the impact of higher education on the formation of assertive behavior. According to the stated goal, the following tasks are defined: 1) to analyze the assertive approach in a higher education institution; 2) determine the quality and level of assertiveness in the student environment.

\section{Methodology and methods}

The educational system of the 21st century aims to solve a fundamentally new global problem - preparing people for life in the context of globalization, forming critical thinking, creating a new personality culture that determines the attitude of man to the world and his behavior in interaction with others. An extremely mobile and dynamic society requires a young person to be independent, active, committed and responsible, able to uphold their point of view without violating the rights of another person, that is, being assertive.

The idea of an assertive personality implies the presence in her of the specified quality of behavior, through which there is a possession of spontaneous reactions, a reasonable expression of emotions, the ability to speak directly about their desires and demands, to express their own point of view, not to be afraid to deny, to insist on their argument, when superfluous or inappropriate; to have the tactics of satisfying one's own requirements and refusing to respond to unacceptable aspirations in such a way that other people's rights are not violated.

Korobkova's research on assertiveness, which she interprets as adequate assessment of circumstances, her own behavior, the way of self-realization and self-development, is extremely relevant in this context (Korobkova, 2000: 138-139).

The assertiveness by students develops on the basis of sociability, which, entrenched in behavior, is a prerequisite for the development of such personality traits as the focus on communication, interest in people, reflection and empathy. Considering the personality of the student in the conditions of the educational institution it is necessary to speak about the formation of skills of assertive behavior, and not constructive aggressiveness, without which revealed assertiveness is impossible. And this is no accident. The fact is that the constructive aggressiveness is based on the philosophy of an active life position, according to which a person stands for the protection of their vital values and interests. This position allows you to attack the abuser, while displaying cruelty, anger and hostility. By producing a constructive aggressiveness by students, it should be understood that such activity can lead to conflicts, mistrust, suspicion, which is extremely unacceptable in the educational process, which is based on the principles of trust, love and respect for the individual, the participant of the educational process (Grebenkin, 2006).

Analyzing the research of Khokhlova, it is necessary to support her opinion that in the conditions of the educational institution the educational work should be carried out in the direction of forming not constructive aggressiveness, but assertive behavior, which means to be active and active, but without harm to others. (Khokhlova, 2008). The basis of such behavior will be non-violent treatment to people and to the world at large. In the educational process, the assertive approach most accurately reflects the democratic tendencies that should emerge during the educational activity. Based on the research of S.A. Medvedeva, L.G. Terletskoy, N.I. Povyakel, T.S. Yatsenko and others, refining their approaches, it should be emphasized, that the most important conditions for promoting the development of student assertiveness are active social and psychological training. The main place in the educational process is occupied by the following conditions of development of assertiveness: inclusion in the content of professional training of knowledge on assertiveness of the future specialist; formation of ideas about themselves and about others as equal subjects of communication; enhancing the subjective experience of students by including them in social communication situations; ensuring the value-meaning attitude to the assertiveness of the future specialist; reflection of emotional content of assertiveness training; creating an atmosphere in the learning process that promotes self-discovery, transformation and development of self-assertiveness, as well as provides an active position of participants through the creation of relationships of trust, support, mutual respect in the group; exchange of experience of assertiveness in real life circumstances. (Medvedeva, 2006).

Due to assertive behavior, the future professional will have the following professionally important qualities: the ability to self-regulate his own behavior, independence from exter- 
nal influences and assessments; knowledge of their rights and responsibilities; adequate assessment of oneself and others; awareness of personal needs and interests; respect for the rights and interests of others; the ability to achieve set goals without manipulating others; ability to persuade, gain affection, seek advice or help from other participants in interpersonal interaction, etc.

Assertive behavior consists in displaying confidence in asserting both their right to dignity and health and to others. The behavioral model of assertiveness characterizes a person worthy, holistic in his or her beliefs, capable of realizing and defending his or her rights. At the same time, such a person recognizes the rights of another. The principles of assertiveness focus on self-affirming values, which creates barriers to manipulative influences. Detected assertive behavior prevents an aggressive, manipulative, passive style of interaction. Therefore, it clearly performs a preventive function. That is why the problem of research and approval of the concept of "assertiveness", "assertive behavior", "assertive interaction", "assertive approach" should contribute to improving the quality not only of the pedagogical process, but also the level of social interaction based on the principles of assertiveness.

\section{Results and discussions}

To clarify the role of higher education in shaping assertive personality behavior, we compared the results of a survey of junior and graduate students. It turned out that contrary to expectations, the levels of assertiveness are decreasing rather than increasing. Subsequently, the data were obtained to support this hypothesis.

For some time, we have studied the values of student youth through various methods and tests, but in this study we were more interested in the readiness of the individual to cooperate, the ability to find a common language, to respect the opinion of others all that is characterized in one word as assertiveness. In the course of the research, we decided to look at how the assertiveness indicators change depending on the course and the life experience of the respondents. Therefore, in the 2014-2015 academic year, we conducted surveys on 1-4 courses of full-time and correspondence department (specialty psychology). To study the level of students' perceptions of assertiveness as a personal quality of behavior, a test - the questionnaire "Study of levels of assertiveness", developed by the authors V. Kapponi, T. Novak.

"The Assertiveness Levels Test" reveals three levels of assertiveness development: Level A: a notion of assertiveness, but this quality is almost never used by students. This situation can be explained by the lack of professional experience, since first and partially senior students do not take this course in psychology (especially correspondence). Those who have received this result are often dissatisfied with themselves and others.

Level B: normal assertiveness, ability to act in the required direction.

Level C: testifies to the existence of an assessment of oneself and one's behavior, the conformity of ideas about oneself as a strong personality, with sufficient freedom of choice, which in turn allows one to build one's life according to the intended goals and objectives.

Students with low levels of assertiveness in a number of situations may not withstand difficulties and external pressure, and in solving difficult issues - they do not demonstrate confidence and resilience, ability to work with "difficult clients" in the future, or in difficult conditions. Such students may not always be in a good mood and persistently achieve their goals.

Our analysis of the data from the test results gave the following picture: the majority of the respondents we surveyed found insufficient awareness of the gist and nature of assertive behavior. While asking about quality, difficulty was observed in the overwhelming majority of respondents who said, "I don't know", "what is the quality?", "I can't say anything about it", aggressiveness, inadequacy, effortful activity $(92.7 \%)$, other respondents $(7.3 \%)$, the most frequently followed were answers about self-sufficiency, self-confidence.

In the process of research, if in the definition of the terms "assertive personality" and "assertive behavior" students gave answers that are worth the weight, let's give some examples of them: assertive personality - "self-confidence", "confident in their thoughts and actions", "complete introspection", "autonomy in decision-making", then the question "What does assertiveness mean?" caused some difficulties. With regard to the definition of "assertive behavior", many students identified it with an assertive personality. Only a small number of those studied differentiated these concepts. For example, "feeling right", "full independence and independence in their actions and deeds", "level of personal harassment", etc.

While asking the question "How assertive behavior affects the level of knowledge acquisition in order to master the future profession?" - the vast majority of students did not identify them with assertive behavior, with possible success in mastering their profession. 
Only a small number of respondents, especially IV year students, felt that they lacked this ability to master and advance in their profession, because they felt "fear", "anxiety", "feeling of imbalance", "feeling of not being recognized in the solution situations that customers may face", etc. There were also students' responses, which emphasized that assertive behavior does not interfere with their professional development, but does not bring special achievements, because for them the "influence of my own self on the situation" and the degree of the motivation in achieving it "... if I can influence something, including the quality of training, then I will have fun, and if not, I will not influence" are important. For example, "I do not miss classes whether they bring me pleasure, interest, or not". Among the answers were those who stated that "at this level, at which I am at present, assertive behavior helps"; "...however, in new situations that I have not been to, I feel very uncomfortable. Because of this, I often try to calculate beforehand all the possible situations that may happen to me". The obtained data allow us to conclude that there are no clear perceptions of the respondents about the assertive behavior of the future psychologist's personality, its peculiarities, mechanisms of detection.

The respondents were more aware of the differences between aggressive and passive (unsure) behavior, and therefore more knowledge. Defining them, respondents were more inclined to identify certain features, such as: characterization of voice (loudness, tone, shouts), gestures (hand movements, strokes), content of speech (insults, threats or justifications), emotional manifestations (anger, feelings guilt). It should be noted, that the proposed list of manifestations is not sufficiently complete. In describing the differences, there were practically no such behavioral characteristics as eye contact, distance, communication, justification of requirements, etc.

While choosing the situations by respondents, in which they show confidence, the following were most often noted: "When I'm sure of my correctness" (70\%), "When I'm not afraid" (30\%), "When I'm feeling well" (30\%), "When they listen to me" (40\%).

As shown in the fig. 1, the increase in indicators of the formation of assertive behavior by age is ascertaining towards positive dynamics from the age of 21 , its peak being determined after 25 years. This is explained by the fact that students gain experience in expanding their knowledge about the phenomenon under study, clearly orienting themselves in what role and place it acquires in professional development, identification with the role of psychologist - practitioner, psychologist - consultant; with experience of assertiveness in the process of interpersonal interaction - confidence, responsibility, trust in yourself and other subjects of educational interaction. The low level of assertive behavior was demonstrated by the first-year and partly the second-year psychology students, in whom the quality of professional development is only being formed.

According to the results of the study, the differences between the state of formation of assertive behavior in students-future psychologists between courses and the form of study were determined. As shown in fig. 2, the increase in the state of formation of assertive behavior up to the peak - observed in students enrolled in the third year, while by the students in the final year a tendency to a slight decrease. This is due to the fact that after passing the practice, students rethink both personal and professional values related to the choice of profession, level of anxiety, responsibility, and at the same time decreases the level of confidence, confidence in oneself, their professional abilities in order to succeed.

In addition, in the context of our quality, the dependence of the state of assertive behavior of psychologic students on the form of study (full-time and part-time) was determined. Higher score on the correspondence form of study is justified by the fact that students are clearly oriented to the profession, to success in employment (most work in the chosen specialty), respectively, such features of assertive behavior as trust, confidence, ability to listen and hear, develop dialogue immersion in one's own and professional problems, solving professional problems, etc. acquire a professional orientation and their awareness at the level of reflection and self-reflection, than is observed in fulltime students at teaching.

\section{Conclusions}

Thus, the instability of a confident position of student youth revealed by us is confirmed by the assertiveness study. At the beginning of the study, students have higher levels of assertiveness than at the end of it, in addition to the correspondence form of study also revealed a higher index than the fulltime. Could this mean that education does not sufficiently influence students' assertive behavior? Of course not. It is worth mentioning the "human capital" hypothesis that education is most likely a human investment in its future, not one that can be used immediately. All efforts that have been spent in the past will be rewarded in the future. Therefore, the formation of an effective educational 


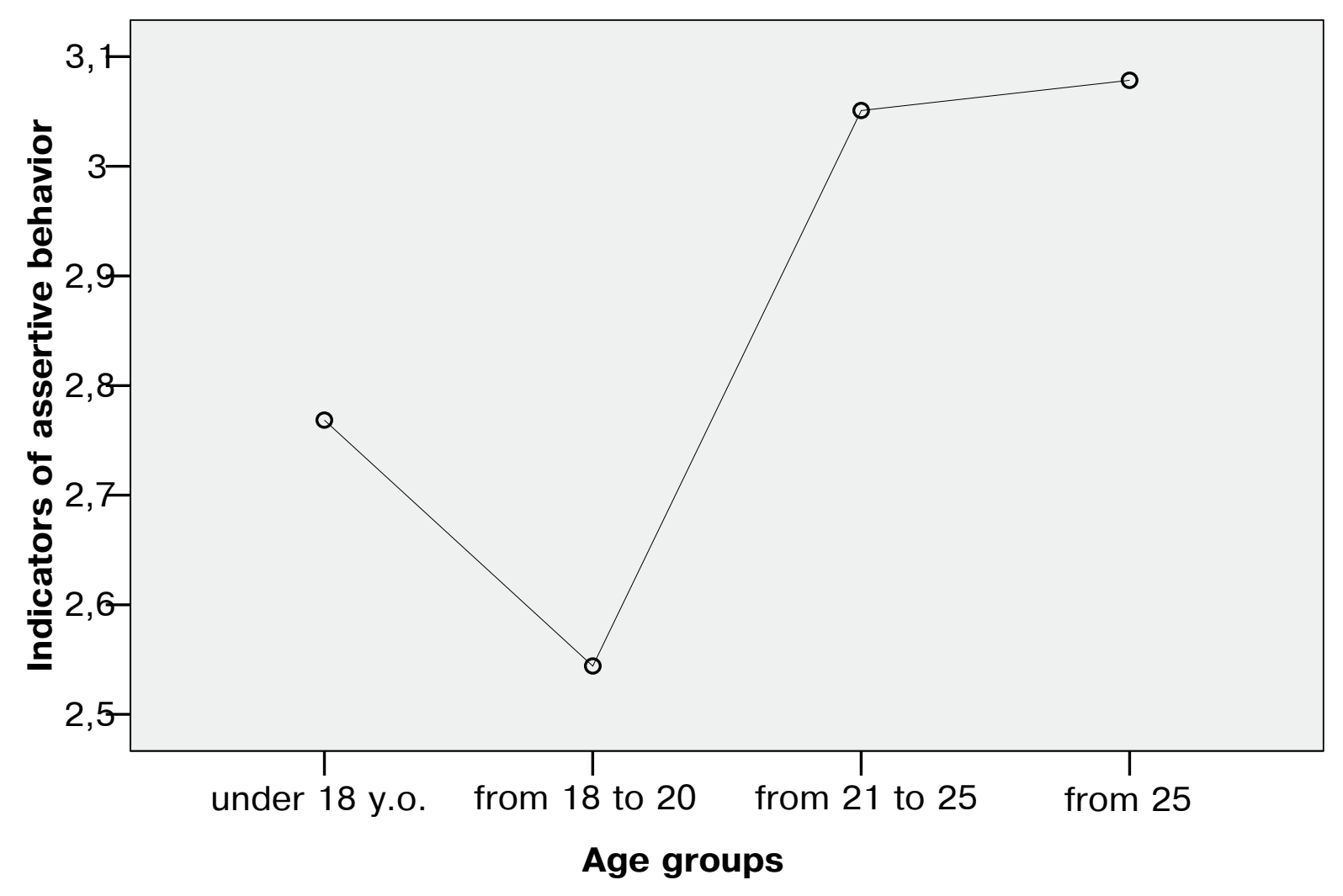

Fig. 1. Features of assertive behavior depending on the age of future psychologists studied

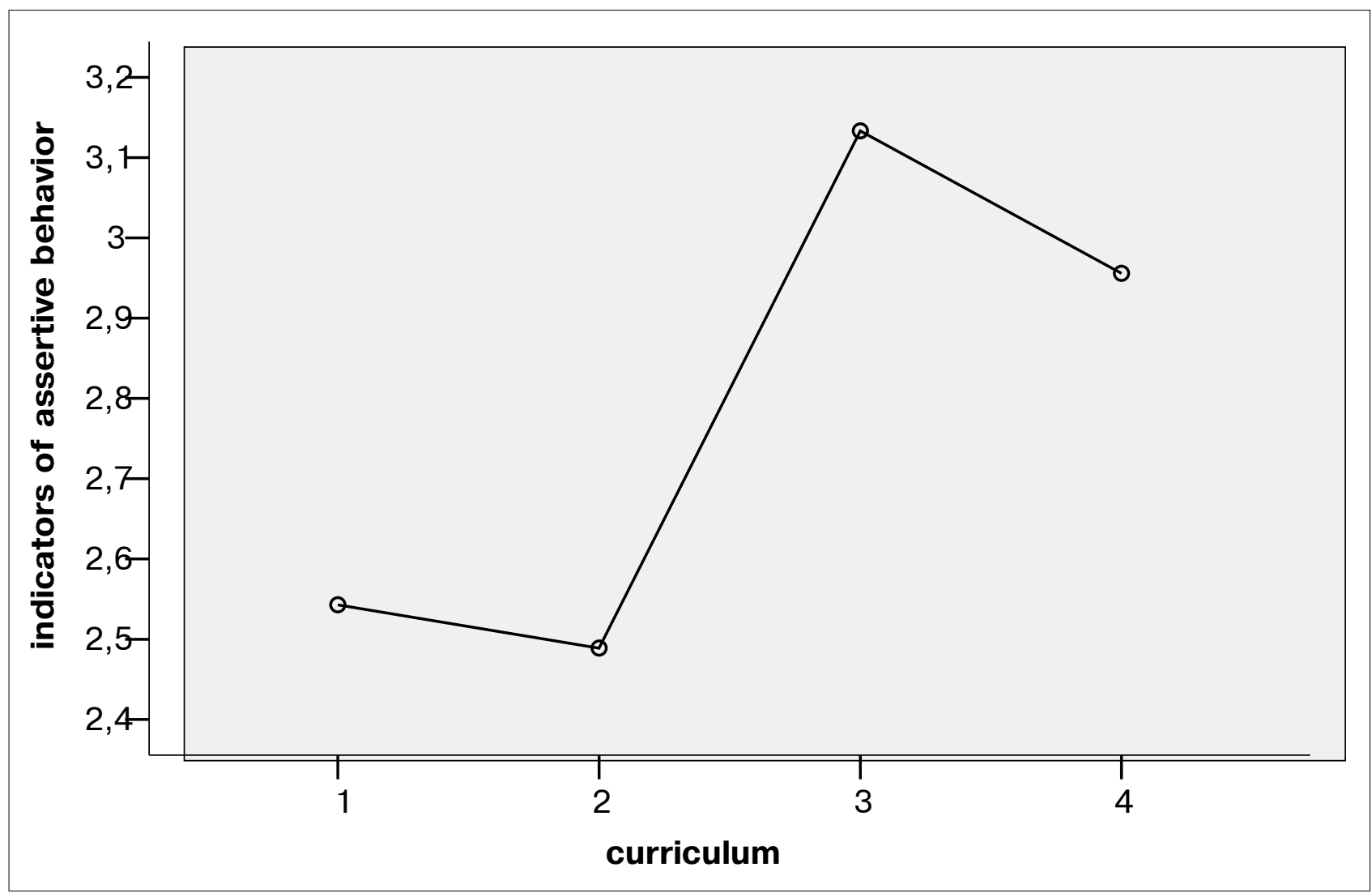

Fig. 2. Features of assertive behavior, depending on the course of study of future psychologists 
program, the content of which should be directed to the discovery of potential personal and professional resource, the development of confidence, mechanisms of self-knowledge, self-realization, self-confidence and self-improvement, where stimulating self-development will be the main tool of the pedagogical and scientific system in the process of developing of the assertive psychological qualities.
It is the quality of education that determines the fate of the individual as well as the whole society as a whole. The presented research can be useful for educators and psychologists for monitoring and correction of assertive behavior of students, as well as being a criterion basis for building a training program aimed at the development of these characteristics.

\section{BIBLIOGRAPHY:}

1. Гребенкин Е.В. Профилактика агрессии и насилия в школе. Ростов на Дону : Феникс, 2006. 157 с.

2. Коробкова Т.А. Ассертивность как вид педагогической коммуникации. Высокие технологии в педагогическом процессе : сборник научных трудов межвузовской науч.-метод. конф. преподавателей вузов, ученых и специалистов, г. Нижний Новгород, 30-31 мая 2000 г. Нижний Новгород : ВИПИ, 2000. С. 138-139.

3. Медведєва С.А. Психологічні особливості розвитку асертивності як умови професійного становлення майбутніх практичних психологів. Наукові записки Інституту психологї̈ імені Г.С. Костюка АПН України / за ред. С.Д. Максименка. Київ : Міленіум, 2006. Вип. 29. С. 459-466.

4. Пилипенко О.І. Удосконалення педагогічної соціалізації на основі асертивного підходу. Вісник Київського міжнародного університету. Серія «Педагогічні науки». 2010. Вип. 1. С. 34-40.

5. Хохлова Е.В. Конструктивная агрессивность в формировании навыков ассертивного поведения студентов вуза : дис. ... канд. психол. наук : 19.00.07. Нижний Новгород, 2008. 220 с.

\section{REFERENCES:}

1. Grebenkin, E.V. (2006). Profilaktika agressii i nasiliia v shkole [Prevention of aggression and violence at school]. Rostov on Don: Feniks [in Russian].

2. Korobkova, T.A. (2000). Assertivnost' kak vid pedagogicheskoj kommunikacii [Assertiveness as a type of pedagogical communication]. Collection of scientific papers from HTPP 2000: Sbornik nauchnyh trudov konferencii "Vysokie tehnologii v pedagogicheskom processe" - The interuniversity scientific methodological conference of university teachers, scientists and specialists "High technologies in the pedagogical process". (pp. 138-139). Nizhnij Novgorod: VIPI [in Russian].

3. Medvedieva, S.A. (2006). Psykholohichni osoblyvosti rozvytku asertyvnosti yak umovy profesiinoho stanovlennia maibutnikh praktychnykh psykholohiv [Psychological features of the development of assertiveness as a condition of professional formation of future practical psychologists]. Naukovi zapysky Instytutu psykholohii imeni H.S. Kostiuka APN Ukrainy - G.S. Kostyuk Institute of Psychology, Academy of Pedagogical Sciences of Ukraine. S.D. Maksymenka (Ed.). Kyiv: Milenium [in Ukrainian].

4. Pylypenko, O.I. (2010). Udoskonalennia pedahohichnoi sotsializatsii na osnovi asertyvnoho pidkhodu [Improvement of pedagogical socialization based on assertive approach]. Pedahohichna teoriia i praktyka-Pedagogical theory and practice, 1, 34-40 [in Ukrainian].

5. Khokhlova E.V. (2008). Konstruktivnaya agressivnost' $\mathrm{v}$ formirovanii navy 'kov assertivnogo povedeniya studentov vuza [Constructive aggressiveness in the formation of assertive behavior skills of university students]. Candidate's thesis. Nizhnij Novgorod: state University of Architecture and Civil Engineering [in Russian]. 